\title{
Separation of Acid Diterpenes of Copaifera cearensis Huber ex Ducke by Flash Chromatography Using Potassium Hydroxide Impregnated Silica Gel
}

\author{
Angelo C. Pinto*, Waldenir F. Braga, Claudia M. Rezende, Francisco M. S. Garrido, Valdir F. Veiga \\ Jr., Lothar Bergter, Maria Lúcia Patitucci and Octávio A. C. Antunes
}

Instituto de Química, Universidade Federal do Rio de Janeiro, CT Bloco A, 21945-970, Rio de Janeiro - RJ, Brazil

\begin{abstract}
O uso de cromatografia sob pressão ("flash chromatography”) utilizando-se coluna de gel de sílica impregnada com hidróxido de potássio levou ao fracionamento dos constituintes químicos de Copaifera cearensis Huber ex Ducke. A fração ácida, após esterificação com diazometano, foi analisada por cromatografia gasosa de alta resolução acoplada à espectrometria de massas ou à espectrometria no infravermelho, possibilitando a identificação de onze diterpenos ácidos. Fracionamentos adicionais da fração ácida por cromatografia líquida de alta eficiência em fase reversa levaram ao isolamento de diversos ácidos diterpênicos e de um sesquiterpênico que foram identificados através de seus dados espectroscópicos. A análise da sílica impregnada com hidróxido de potássio mostrou que, além da deposição do hidróxido na superfície da sílica, ocorreu troca iônica com formação de resíduos Si-OK.
\end{abstract}

Various acid diterpenes of Copaifera cearensis Huber ex Ducke were isolated from the crude extract by flash Silica Gel/Potassium Hydroxide Chromatography. The main components were identified by GC-MS analyses. Further fractionation by reversed phase (RP) semi-preparative HPLC allowed isolation and identification of minor components and provided additional spectral data of those compounds. It was possible to detect the presence of eleven acid diterpenes in addition to a sesquiterpene acid. In addition to potassium hydroxide deposition on the silica surface, the presence of $\mathrm{Si-OK}$ residues, resulting from a cation exchange process, was established.

Keywords: Copaifera cearensis, acidic diterpene fraction, GC-MS analysis, silica gel/potassium hydroxide chromatography

\section{Introduction}

Copaiba oils are exuded from the trunks of trees belonging to the Copaifera genus and can be found in many drugstores in Brazil as a phytotherapeutical oil ${ }^{1,2}$. These trees are found in northern and northeastern Brazil, as well as in Venezuela, Colombia, Guyana, French Guiana and Suriname ${ }^{3,4}$. The copaiba oils are known from folk medicine due to their antiseptic, antiinflammatory; and antiblenorrhagic properties ${ }^{5}$. These oils were first described by Gabriel Soares de Souza in $1587^{6}$ and were included in "The British Pharmacopoeia" in 1677 and "The United States Pharmacopoeia" in $1820^{7}$. Pellegrino et al. have studied the use of these oils against infections by Schistosoma mansoni ${ }^{8}$. Basile et al have shown the analgesic and antiinflammatory properties of these oils ${ }^{9}$, confirmed by Fernandes et al. ${ }^{10}$. All these studies were carried out with the crude oils, therefore showing the need of a better understanding of which component(s) would be responsible for the pharmacological activities ascribed to the oils. Several Copaifera spp. are known, including Copaifera cearensis Huber ex Ducke ${ }^{5}$, whose acid composition is described in the present work. We also report the characterization of $\mathrm{KOH}$-impregnated silica ge ${ }^{11,12}$ by IR spectroscopy.

\section{Experimental}

\section{Materialsandmethods}

Crude oil from Copaifera cearensis was obtained as an exudate from direct perforation of the trunk of the tree. Melting points were determined on a Kofler block and are uncorrected. Infrared (IR) spectra were recorded as $\mathrm{KBr}$ pellets or fluorolube mull on a Perkin Elmer 1760X FT or Nicolet Magma 760 FT (for silica characterization) spectrophotometers from 6000 to $400 \mathrm{~cm}^{-1}$. One- and twodimensional (1D and 2D) nuclear magnetic resonance (NMR) experiments were carried out on a Bruker $300 \mathrm{AC}-\mathrm{P}$ 
spectrometer (300.13 MHz for ${ }^{1} \mathrm{H}$ NMR and $75.25 \mathrm{MHz}$ for ${ }^{13} \mathrm{C} \mathrm{NMR}$ ) using $\mathrm{CDCl}_{3}$ as solvent. ${ }^{13} \mathrm{C} \mathrm{NMR}$ were obtained under Composite Pulse Decoupling ( $2 \mu \mathrm{s} ; 90^{\circ} 4.4$ $\mathrm{ms})$. Distortionless Enhancement by Polarization Transfer (DEPT) ${ }^{13} \mathrm{C}$ NMR spectra were obtained considering $J(\mathrm{CH}) 145 \mathrm{~Hz}$. Shift Correlated Spectroscopy (COSY) ${ }^{1} \mathrm{H}$ NMR spectra were obtained using standard Bruker software COSY.AUR program (512 points F2; 256 points F1). Heteronuclear Shift Correlation (HETCOR) ${ }^{13}$ C NMR spectra were obtained using XHCOORD.AUR program (2048 points $\mathrm{F} 2{ }^{13} \mathrm{C} ; 256$ points $\mathrm{F} 1{ }^{1} \mathrm{H} ; J(\mathrm{CH}) 10 \mathrm{~Hz}$ for pulse intervals). A Hewlett-Packard HP 5890A Gas Chromatograph equipped with capillary columns, oncolumn or split/splitless injectors and a flame ionization detector (FID), was used. A Hewlett-Packard HP 5890A Gas Chromatograph equipped with a capillary column (BP5-SGE, $12 \mathrm{~m}, 0.33 \mathrm{~mm}, 1.0 \mathrm{~mm}, \mathrm{He}$ as the carrier gas: 10 psi) and on-column injector (SGE 021) coupled to a FTIR HP 5965A (4000 - $750 \mathrm{~cm}^{-1}$ ), was used. Transfer line and IR cell were kept at $250^{\circ} \mathrm{C}$. GC conditions: 40 to $160^{\circ} \mathrm{C}$ at $50^{\circ} \mathrm{C} \mathrm{min}{ }^{-1}, 160^{\circ} \mathrm{C}(1 \mathrm{~min})$ to $270^{\circ} \mathrm{C}$ at $5^{\circ} \mathrm{C} \mathrm{min}-1$. A Hewlett-Packard GC-MS system HP 5988, electron impact (EI), at $70 \mathrm{eV}, 200^{\circ} \mathrm{C}$ ion source temperature, or chemical ionization (CI), $230 \mathrm{eV}, \mathrm{CH}_{4}$ as the reagent gas, $100^{\circ} \mathrm{C}$ ion source temperature, equipped with a capillary column (He as carrier gas), on-column (SGE 021) or split/splitless injectors, was used. Flash chromatography using potassium hydroxide modified silica was carried out with the material produced as follows: $200 \mathrm{~g}$ of silica gel 60 (230-400 mesh) in $i \mathrm{PrOH}(1 \mathrm{~L})$ were stirred with $400 \mathrm{~mL}$ of a saturated solution of $\mathrm{KOH}(50 \mathrm{~g})$ for a period of $10 \mathrm{~min}^{11,12}$. This mixture was then transferred into a glass column and washed with $800 \mathrm{~mL}$ of hexane, under air pressure (less than $1 \mathrm{~atm})^{13}$. Crude oil $(5.0 \mathrm{~g})$ was then applied to the top of this column and eluted successively, under air pressure, with $400 \mathrm{~mL}$ of hexane, $\mathrm{CH}_{2} \mathrm{Cl}_{2}$ and $\mathrm{MeOH}$ respectively. The $\mathrm{MeOH}$ fraction was concentrated to a quarter of the initial volume, acidified to $\mathrm{pH} 4$ and extracted with $\mathrm{CH}_{2} \mathrm{Cl}_{2}$ which was then evaporated. The $\mathrm{CH}_{2} \mathrm{~N}_{2}$ solution used to produce methyl esters was obtained as follows: a solution of $45 \mathrm{~g}$ of Diazald ${ }^{\circledR}$ in $450 \mathrm{~mL}$ of $\mathrm{Et}_{2} \mathrm{O}$ was slowly added to a mixture of $45 \mathrm{~g}$ of $\mathrm{KOH}, 90 \mathrm{~mL}$ of $\mathrm{H}_{2} \mathrm{O}$ and $72 \mathrm{~mL}$ of EtOH, so producing a very gentle distillation of $\mathrm{CH}_{2} \mathrm{~N}_{2} / \mathrm{Et}_{2} \mathrm{O}$, which was collected on an ice bath and used whenever needed.

\section{Spectraldata}

Eperuic acid methyl ester (1) ${ }^{14}$ : (GC) EIMS m/z 320 ( $\left.\mathrm{M}^{+}, 35 \%\right), 305$ (90), 289 (7), 192 (10), 191 (20), 177 (60), 137 (100); (GC) CIMS m/z $321\left(\mathrm{M}^{+}+1,100 \%\right)$; (GC) IR $v_{\max } / \mathrm{cm}^{-1} 3087,2940,2881,1757,1642,1162,892$.
Cativic acid methyl ester (2) ${ }^{15}$ : (GC) EIMS m/z 320 $\left(\mathrm{M}^{+}, 20 \%\right), 305$ (40), 289 (14), 264 (10), 196 (27), 191 (80), 124 (20), 122 (100); (GC) CIMS m/z $321\left(\mathrm{M}^{+}+1\right.$, 100\%); (GC) IR $v_{\text {max }} / \mathrm{cm}^{-1} 2992,2858,1757,1160,833$.

Copalic acid methyl ester (3) ${ }^{16}$ : (GC) EIMS m/z 318 $\left(\mathrm{M}^{+}, 18 \%\right), 303$ (70), 286 (3), 271 (10), 244 (20), 229 (13), 205 (18), 192 (2), 177 (20); (GC) CIMS m/z $319\left(\mathrm{M}^{+}+1\right.$, $100 \%$ ); (GC) $v_{\max } / \mathrm{cm}^{-1} 3087,2940,2854,1738,1648$, 1221, 1190, 893.

Kolavenic acid methyl ester (4) ${ }^{17}$ : (GC) EIMS m/z 318 $\left(\mathrm{M}^{+}, 14 \%\right), 303$ (18), 275 (10), 271 (8), 243 (20), 191 (32), 189 (100), 175 (20); (GC) CIMS m/z $319\left(\mathrm{M}^{+}+1,100 \%\right)$; (GC) $v_{\max } / \mathrm{cm}^{-1} 2953,1738,1648,1221,1150,862$.

Crolechinic acid methyl ester (5) ${ }^{18}$ : (GC) EIMS $\mathrm{m} / \mathrm{z}$ $332\left(\mathrm{M}^{+}, 4 \%\right), 317$ (3), 273 (6), 237 (75), 95 (36), 81 (100); (GC) CIMS m/z $333\left(\mathrm{M}^{+}+1,100 \%\right)$; (GC) $v_{\max } / \mathrm{cm}^{-1} 2943$, 2881, 1747, 1559, 1166, 875; ${ }^{13} \mathrm{C}$ NMR $\delta 14.8$ (C-19), 16.0 (C-17), 18.0 (C-20), 18.1 (C-12), 21.0 (C-1), 24.9 (C3), 26.2 (C-2), 27.2 (C-7), 36.6 (C-8), 37.3 (C-5), 38.4 (C11), 38.9 (C-9), 39.9 (C-6), 49.3 (C-10), 50.9 (MeO), 57.6 (C-4), 111.0 (C-14), 125.6 (C-13), 138.4 (C-16), 142.7 (C15), 174.9 (C-18).

Hardwickiic acid methyl ester (6) ${ }^{18,19}$ : (GC) EIMS $m$ / z $330\left(\mathrm{M}^{+}, 12 \%\right), 315(5), 299$ (10), 283 (12), 235 (45), 203 (65), 175 (20), 139 (100), 96 (60), 95 (42), 81 (80); (GC) CIMS $m / z 331\left(\mathrm{M}^{+}+1,100 \%\right)$; (GC) $v_{\max } / \mathrm{cm}^{-1} 2962,2884$, $1733,1638,1560,1232,1166,936 ;{ }^{13} \mathrm{C}$ NMR $\delta 15.9(\mathrm{C}-$ 17), 17.5 (C-1), 18.2 (C-20), 18.6 (C-12), 20.7 (C-19), 27.1 (C-7), 27.3 (C-2), 35.9 (C-6), 36.3 (C-8), 37.3 (C-5), 38.6 (C-11), 38.8 (C-9), 46.6 (C-10), $51.1(\mathrm{MeO}), 111.0$ (C-14), 125.6 (C-13), 136.8 (C-3), 138.4 (C-16), 142.5 (C-4), 142.7 (C-15), 167.9 (C-18).

3-Methyl-5(2',2',6'-trimethyl-6'-hydroxycyclohexyl)pentanoic acid methyl ester (7a) ${ }^{20}$ (GC) EIMS $\mathrm{m} / \mathrm{z}, 270$ $\left(\mathrm{M}^{+}, 2 \%\right), 252$ (7), $238(5), 196(8), 195$ (10), 177 (10), 153 (20), 112 (75), 109 (75), 43 (100); (GC) CIMS m/z 253 $\left(\mathrm{M}^{+}+1-18,100 \%\right), 271\left(\mathrm{M}^{+}+1,2\right) ;(\mathrm{GC}) v_{\max } / \mathrm{cm}^{-1} 2941$, 2880, 1757, 1165.

3-Methyl-5(2',2',6'-trimethyl-6'-hydroxycyclohexyl)pentanoic acid (7b) ${ }^{20}$ : ${ }^{1} \mathrm{H}$ NMR $\delta 0.77$ (s, 3H), 0.89 (s, $3 \mathrm{H}), 0.95$ (d, J $6.5 \mathrm{~Hz}, 3 \mathrm{H}), 1.07$ (t, J 4.5 Hz, 1H), 1.14 (s, $3 \mathrm{H}), 1.2-1.7(\mathrm{~m}, 10 \mathrm{H}), 1.74(\mathrm{~m}, 1 \mathrm{H}), 1.87-2.00(\mathrm{~m}, 1 \mathrm{H})$, $2.10(\mathrm{dd}, J 15$ and $7.5 \mathrm{~Hz}, 1 \mathrm{H}), 2.34(\mathrm{dd}, J 15$ and $6.5 \mathrm{~Hz}$, $1 \mathrm{H}) ;{ }^{13} \mathrm{C}$ NMR $\delta 19.8$ (C-6), 20.4 (C-4'), 21.3 (C-8), 23.0 (C-9), 23.1 (C-5), 30.8 (C-3), 32.8 (C-7), 35.5 (C-6'), 39.6 (C-4), 41.3 (C-2), 41.4 (C-5'), 43.1 (C-2'), 57.0 (C-1'), 74.9 (C-2'), 178.4 (C-1).

Clerodan-15,18-dioic acid dimethyl ester (8): (GC) EIMS m/z 335 (M+-31, 2\%), 307 (3), 251 (4), 237 (100), 
205 (55), 177 (70); (GC) CIMS m/z $395\left(\mathrm{M}^{+}+29,15 \%\right)$, $335\left(\mathrm{M}^{+}+1-32,18\right), 307\left(\mathrm{M}^{+}+1-60,100\right) ;(\mathrm{GC}) \mathrm{v}_{\max } / \mathrm{cm}^{-1}$ 2958, 2882, 1749, 1166; ${ }^{1} \mathrm{H}$ NMR $\delta 0.68$ (s, 3H), 0.75 (d, $J 6.0 \mathrm{~Hz}, 3 \mathrm{H}), 0.93$ (d, J $6.8 \mathrm{~Hz}, 3 \mathrm{H}), 0.99$ (s, 3H), 1.0-1.5 $(\mathrm{m}, 16 \mathrm{H}), 1.5-2.0(\mathrm{~m}, 3 \mathrm{H}), 2.1(\mathrm{dd}, J 7.0$ and $3.0 \mathrm{~Hz}, 1 \mathrm{H}), 2.2$ $(\mathrm{d}, J 7.0 \mathrm{~Hz}, 1 \mathrm{H}), 2.3(\mathrm{dd}, J 12$ and $6 \mathrm{~Hz}, 1 \mathrm{H}), 3.70(\mathrm{~s}, 3 \mathrm{H})$, $3.76(\mathrm{~s}, 3 \mathrm{H}) ;{ }^{13} \mathrm{C}$ NMR $\delta 14.8$ (C-19), $15.9(\mathrm{C}-17), 18.2$ (C20), 19.8 (C-16), 21.0 (C-1), 24.9 (C-3), 26.2 (C-2), 27.1 (C-7), 29.3 (C-12), 31.0 (C-13), 35.1 (C-11), 36.4 (C-8), 37.3 (C-5), 38.7 (C-9), 39.8 (C-6), 41.5 (C-14), 49.2 (C10), 50.8 (MeO-C-19), 51.3 (MeO-C-15), 57.5 (C-4), 173.6 (C-15), 175.0 (C-18).

Clerod-3-en-15,18-dioic acid dimethyl ester $(9)^{21}$ : (GC) EIMS m/z 333 (M+-31, 28\%), 332 (100), 235 (18), 203 (29), 175 (20), 139 (53); (GC) CIMS m/z $393\left(\mathrm{M}^{+}+29\right.$, $10 \%), 333\left(\mathrm{M}^{+}+1-32,100\right)$.

Labdanolic acid methyl ester (10) ${ }^{22}$ : (GC) EIMS m/z 338 $\left(\mathrm{M}^{+}, 2 \%\right), 323$ (2), 320 (5), 305 (10), 267 (10), 235 (10), 191 (12), 177 (30), 144 (85), 125 (85), 101 (85), 69 (100); (GC) CIMS m/z $339\left(\mathrm{M}^{+}+1,5 \%\right), 321\left(\mathrm{M}^{+}+1-18,100\right)$; (GC) $v_{\max }$ $/ \mathrm{cm}^{-1} 3632,2936,2880,1757,1161,1085 ;{ }^{1} \mathrm{H}$ NMR $\delta 0.78$ $(\mathrm{s}, 6 \mathrm{H}), 0.88(\mathrm{~s}, 3 \mathrm{H}), 0.95(\mathrm{~d}, J 6.50 \mathrm{~Hz}, 3 \mathrm{H}), 1.01(\mathrm{t}, J 3.10 \mathrm{~Hz}$, $1 \mathrm{H}), 1.15(\mathrm{~s}, 3 \mathrm{H}), 1.2-1.3(\mathrm{~m}, 2 \mathrm{H}), 1.3-1.5(\mathrm{~m}, 6 \mathrm{H}), 1.5-1.7(\mathrm{~m}$, $6 \mathrm{H}), 1.7-2.4(\mathrm{~m}, 6 \mathrm{H}), 2.35(\mathrm{dd}, J 15.0$ and $6.5 \mathrm{~Hz}, 1 \mathrm{H}), 3.68$ (s, $3 \mathrm{H}) ;{ }^{13} \mathrm{C}$ NMR $\delta 15.5$ (C-20), 18.5 (C-2), 20.0 (C-16), 20.6 (C-6), 21.5 (C-18), 22.4 (C-11), 24.0 (C-17), 31.1 (C-13), 33.3 (C-4), 33.4 (C-19), 39.2 (C-10), 39.7 (C-12), 40.3 (C-1), 41.3 (C-3), 42.0 (C-14), 44.5 (C-7), 51.4 (MeO-C-15), 56.2 (C-5), 62.1 (C-9), 74.3 (C-8), 174.0 (C-15).

Patagonic acid methyl ester (11) 23,24: (GC) EIMS $\mathrm{m} / \mathrm{z}$ 315 (20\%), 314 (100), 299 (7), 271 (10), 203 (8), 175 (30), 139 (18), 105 (25); (GC) $v_{\max } / \mathrm{cm}^{-1} 2957,2885,1787$, $1733,1639,1232,1166,1063,821 ;{ }^{1} \mathrm{H}$ NMR $\delta 0.76(\mathrm{~s}$, $3 \mathrm{H}), 0.83$ (d, J 6.5 Hz, 3H), 1.29 (s, 3H), 3.74 (s, 3H), 4.85 (dd, $J 2 \mathrm{~Hz}, 2 \mathrm{H}), 6.66$ (t, J $4 \mathrm{~Hz}, 1 \mathrm{H}), 7.14(\mathrm{t}, J 3 \mathrm{~Hz}, 1 \mathrm{H})$; ${ }^{13} \mathrm{C}$ NMR $\delta 15.4$ (C-17), 17.5 (C-1), 18.1 (C-20), 19.0 (C12), 20.7 (C-19), 27.1 (C-7), 27.2 (C-2), 36.0 (C-11), 36.3 (C-6), 36.3 (C-8), 37.6 (C-5), 38.7 (C-9), 46.6 (C-10), 51.1 (MeO-C-19), 70.1 (C-15), 135.0 (C-13), 136.9 (C-3), 142.3 (C-4), 143.4 (C-14), 167.7 (C-18), 174.2 (C-16).

Clerod-3-en-15,16-olide-18-oic acid methyl ester (12) $)^{25}$ : (GC) EIMS m/z $348\left(\mathrm{M}^{+}, 3 \%\right), 316$ (6), 289 (8), 237 (100), 205 (25), 177 (40); (GC) $v_{\max } / \mathrm{cm}^{-1} 2943,2884$, $1787,1750,1146,1062 ;{ }^{1} \mathrm{H}$ NMR $\delta 0.72(\mathrm{~s}, 3 \mathrm{H}), 0.80(\mathrm{~d}$, $J 6.5 \mathrm{~Hz}, 3 \mathrm{H}), 1.04$ (s, 3H), 3.63 (s, 3H); ${ }^{13} \mathrm{C}$ NMR $\delta 14.8$ (C-19), 15.9 (C-17), 18.0 (C-20), 18.9 (C-12), 21.0 (C-1), 24.9 (C-3), 26.1 (C-2), 27.1 (C-7), 35.6 (C-11), 36.6 (C-8), 37.3 (C-5), 38.8 (C-9), 39.8 (C-6), 49.2 (C-10), 50.9 (MeOC-19), 57.4 (C-4), 70.1 (C-15), 134.9 (C-13), 142.3 (C-14), 174.3 (C-16), 174.9 (C-18).

\section{Results and Discussion}

\section{Characterization of the modified silica}

Useful information on the silica surface and $\mathrm{SiO}_{2}$ network can be obtained by IR spectroscopy which is therefore a good method to study silica modifications. Detailed interpretation of the IR of various forms of silica has been published in the literature ${ }^{26-31}$.

The IR spectra of silica gel 60 (silica-1) and of the sample treated with a solution of $\mathrm{KOH}(5 \%)$ in $i \mathrm{PrOH}$ (silica-2) are shown in Table 1 . The IR spectra of these samples are very similar in the siloxane bulk region (1500 to $400 \mathrm{~cm}^{-1}$ ), which suggests no or only minor changes in the bulk of the $\mathrm{SiO}_{2}$ particles. However, the position of the absorption assigned to the Si-OX stretching vibration (a surface mode of Si-OX groups) is shifted from $977 \mathrm{~cm}^{-1}$, in the pure silica to $963 \mathrm{~cm}^{-1}$, which can be attributed to the exchange of $\mathrm{H}^{+}$by $\mathrm{K}^{+}$on the surface of the silica particles. In the silanol and water regions (6000 to $1600 \mathrm{~cm}^{-1}$ ) changes in the bands shapes and positions are observed and the absorption due to the combination of stretching and deformation modes of the $\mathrm{Si}-\mathrm{OH}$ groups is not observed in the silica- 2 spectrum. These results correlate with a large decrease in the number of $-\mathrm{SiOH}$ surface groups and indicate a significant modification on the silica surface. When $0.50 \mathrm{~g}$ of silica- 2 is washed with $50 \mathrm{~mL}$ of water, the $\mathrm{pH}$ of the resulting solution is equal to 9.5 and after 20 washings (1L of water) the $\mathrm{pH}$ stabilizes at 6.0. The washings of silica- 1 with $50 \mathrm{~mL}$ of water result in a solution of $\mathrm{pH} 5.5$ and this $\mathrm{pH}$ is the same after 20 washings. The IR spectrum of silica-3 (prepared by washing silica- 2 with $1 \mathrm{~L}$ of water) is very similar to that of silica-2, in the 1500 to $400 \mathrm{~cm}^{-1}$ region (see Table 1). The absorption assigned to the $\mathrm{Si}-\mathrm{OX}$ stretching vibration is observed at $966 \mathrm{~cm}^{-1}$, which indicates that the washing procedure removes very few $\mathrm{K}^{+}$ions from the silica surface. In the 6000 to $1600 \mathrm{~cm}^{-1}$ region only minor modifications of bands, shapes and positions could be observed. An additional important observation is the absence of any intense band that could be attributed to silicate stretching modes in the residue from the washings. These results can be explained by the presence of adsorbed $\mathrm{KOH}$ on the silica- 2 surface that is eliminated by washing. The decrease in the surface area (BET method) from $246 \mathrm{~m}^{2} \mathrm{~g}^{-1}$ (silica-1) to $68 \mathrm{~m}^{2} \mathrm{~g}^{-1}$ (silica-2) is another evidence of $\mathrm{KOH}$ deposition on the silica surface.

The modifications of the silica surface can also be analyzed by the changes in the stretching frequency of the surface adsorbed water. The absorptions at $1628 \mathrm{~cm}^{-1}$, $1639 \mathrm{~cm}^{-1}$ and $1631 \mathrm{~cm}^{-1}, v_{2}$, were assigned to silica-1, silica-2 and silica-3, respectively suggesting that in the 
Table 1. Assignments of the observed absorption bands $/ \mathrm{cm}^{-1}$

\begin{tabular}{lccc}
\hline ASSIGNMENT & SILICA-1 & SILICA-2 & SILICA-3 \\
\hline$\left(v_{2}+v_{3}\right) \mathrm{H}_{2} \mathrm{O}$ & 5274 & 5250 & 5263 \\
$(\mathrm{v}+\delta) \mathrm{Si}-\mathrm{OH}$ & 4532 & - & $4533^{\mathrm{a}}$ \\
& 4490 & - & $4476^{\mathrm{a}}$ \\
$(\mathrm{v}) \mathrm{OH}$ & 3665 & 3598 & 3630 \\
& 3405 & 3417 & 3395 \\
& 3248 & 3272 & 3296 \\
$\mathrm{SiO}_{2}$ network overtones & & & \\
or combinations & 1984 & - & 1988 \\
$\mathrm{v}_{2} \mathrm{H}_{2} \mathrm{O}$ & 1872 & 1870 & 1870 \\
$\mathrm{SiO}_{4}$ asymmetric stretching & 1628 & 1639 & 1631 \\
& 1170 & 1170 & 1170 \\
$\delta \mathrm{Si} \mathrm{OX}$ & 1105 & 1101 & 1102 \\
$\mathrm{SiO}_{4}$ symmetric stretching & 801 & 800 & 800 \\
$\delta \mathrm{Si}^{-O} \mathrm{O}$ Si & 471 & 472 & 472 \\
\hline
\end{tabular}

avery weak absorpsion.

three samples the water molecules are proton donors ${ }^{31}$. Thus, the basicity of the silica surface can be characterized by an analysis of the shapes and positions of the bands associated with the surface adsorbed water vibrational modes ${ }^{31,32}$. The greater the wavenumber of the $v_{2}$ absorption, the higher the basicity of the silica surface 31,32 and therefore the increasing order of basicity is silica- $1<$ silica-3 < silica- 2 . As expected, a decrease in the wavenumber of the band due to the combination $v_{2}+v_{3}$ of the hydrogen-bonded $\mathrm{H}_{2} \mathrm{O}$ molecules is observed and follows the trend silica-1 $>$ silica$3>$ silica-2. An increase in their width is also noted in the order silica-1 < silica-3 < silica-2. So, the order of basicity also agrees with the variation in the position and shape of this band. These results agree with the hypothesis of deposition of $\mathrm{KOH}$ on the surface of silica-2, with the elimination of this $\mathrm{KOH}$ by washing in the silica-3, and with the presence of $-\mathrm{SiO}^{-} \mathrm{K}^{+}$groups on the surface of silica-3.

\section{Separation and characterization of the acid diterpenes of Copaiferacearensis Huber exDucke}

The IR spectrum of the crude copaiba oil showed an absorption at $1740 \mathrm{~cm}^{-1}\left(\mathrm{v}_{\mathrm{C}=\mathrm{O}}\right)$ and a broad, medium, band between 3500 and $2600 \mathrm{~cm}^{-1}$, attributed to carboxylic acids. After methylation of the crude oil with $\mathrm{CH}_{2} \mathrm{~N}_{2}$, the IR spectrum showed a strong absorption at $3300 \mathrm{~cm}^{-1}$ (hydroxyl band), and absorptions at $1160 \mathrm{~cm}^{-1}\left(\mathrm{v}_{\mathrm{C}-\mathrm{O}}\right)$, and $1740 \mathrm{~cm}^{-1}\left(\mathrm{v}_{\mathrm{C}=\mathrm{O}}\right)$, thus showing the presence of carboxylic acids in the crude extract which confirmed previously published results.

GC analysis of the crude oil showed broad tailing peaks between 6 and $20 \mathrm{~min}$, which were related to the presence of free carboxylic acids. GC analysis of the methylated extract led to a significant improvement of this profile, therefore confirming the presence of carboxylic acids in the extract.

In order to verify the effect of the injection mode, GC analysis of the crude oil was then carried out by using the cold on-column injection mode. The chromatogram obtained showed no difference from the previous one, under split injection mode, i.e., no artifact formation was observed due to the injection mode.

Flash chromatography of $5 \mathrm{~g}$ of the crude oil on silica gel/potassium hydroxide was then successively eluted with $400 \mathrm{~mL}$ portions of hexane (fraction 1, $2.60 \mathrm{~g}$ ), $\mathrm{CH}_{2} \mathrm{Cl}_{2}$ (fraction 2, $0.50 \mathrm{~g}$ ) and $\mathrm{MeOH}$ (fraction 3, $1.70 \mathrm{~g}$ ), 96\% of the original mass was recovered. The combination of the GC chromatograms of fractions 1,2 and 3 (after methylation) reproduced qualitatively and quantitatively the chromatogram of the crude oil after methylation.
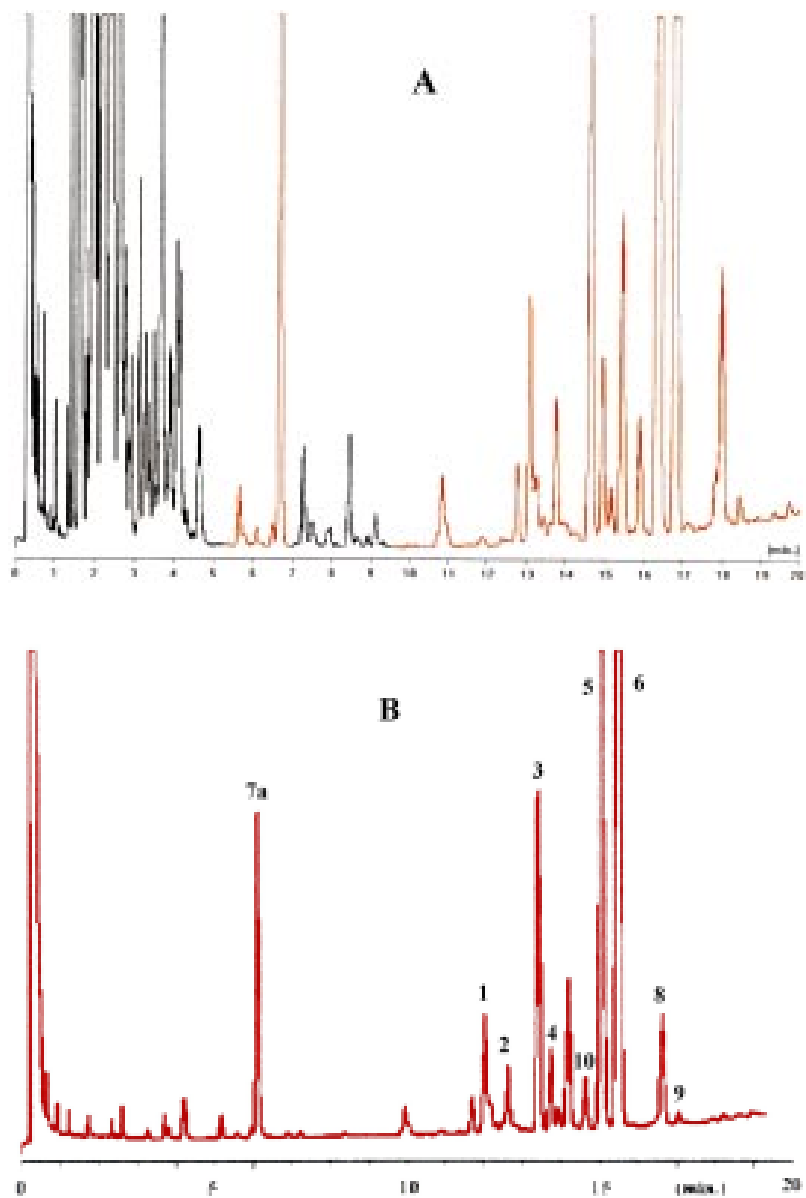

Figure 1. A) Chromatogram of the Copaifera cearensis oil (esterified). B) Chromatogram of the acid fraction separated by the $\mathrm{KOH}$-modified silica gel column. (after esterification - fraction 3).

The identified methyl esters of the acids are: 1 eperuic; 2 cativic; 3 copalic; 4 kolavenic; 5 clorechinic; 6 hardwickiic; 7a 3-methyl5(2',2',6' -trimethyl-6'-hydroxycyclohexyl)-pentanoic; 8 clerodan15,18-dioic; 9 3-cleroden-15,18-dioic; 10 labdanolic. 
The IR spectrum of fraction 3 showed a carboxylic acid absorption between 3500 and $2500 \mathrm{~cm}^{-1}$ which disappeared after methylation, in addition to a $\mathrm{v}_{\mathrm{C}=\mathrm{O}}$ at $1750 \mathrm{~cm}^{-1}$.

GC-MS analyses of methylated fraction 3 were undertaken and based on comparisons with the Wiley-HP 59943P database and other published data, it was possible to identify the methyl esters of eperuic acid (1), cativic acid (2), copalic acid (3), kolavenic acid (4), crolechinic acid (5) and hardwickiic acid (15,16-epoxy-3,13(16),14-clerodatrien18-oic acid) (6) (Scheme 1).

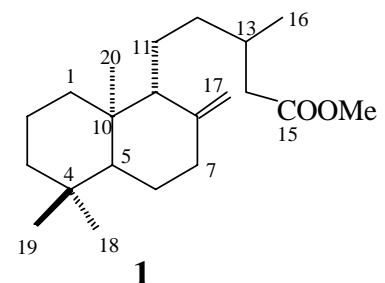<smiles>CC(=O)C1CCC2C(=CCC3C(C)(C)CCC[C@@]23C)C1C</smiles><smiles>CC(=O)C1=C2CCC3C(C)(C)CCC[C@]3(C)[C@@H]2CC1</smiles>
3<smiles>CC(=O)C1=C(C)CC[C@@]2(C)[C@@H]3CCC=C(C)[C@@]3(C)CC[C@@H]12</smiles>

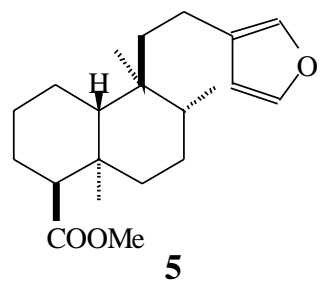<smiles>COC(=O)C1=CCCC[C@]12CC[C@H]1[C@@H]3COC[C@H]3CC[C@H]12</smiles>

Scheme 1.

Further fractionation of the free carboxylic acids present in fraction 3 was carried out by semipreparative HPLC (300 $\mathrm{mm}, 7.8 \mathrm{~mm}$ ID, $5 \mathrm{~mm}$, $\mu$-bondapak C-18). Elution of fraction 3 with $85 \% \mathrm{MeOH} / \mathrm{H}_{2} \mathrm{O}$ (acidified to $\mathrm{pH} 5$ with $\mathrm{H}_{3} \mathrm{PO}_{4}$ ), at $2.0 \mathrm{~mL} \mathrm{~min}-1$ under RI detection, allowed collection of 5 fractions (LC-1 to LC-5). These fractions were then methylated and analyzed by GC-MS. LC-1 was found to be a single compound, a sesquiterpene acid (methyl ester 7a), LC-2, two diterpene acids (methyl esters 8 and 9), and LC-3 contained a diterpene acid (methyl ester 10) as the a main constituent. LC-4 was composed of hardwickiic acid (methyl ester 6) and crolechinic acid (methyl ester 5), in addition to two other components. Finally, LC-5 was a complex mixture in which eperuic acid (methyl ester 1) and copalic acid (methyl ester3) were present (Scheme 2).

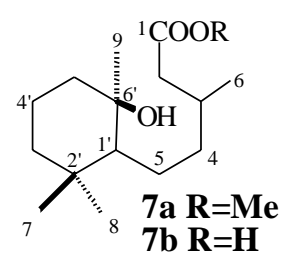

9

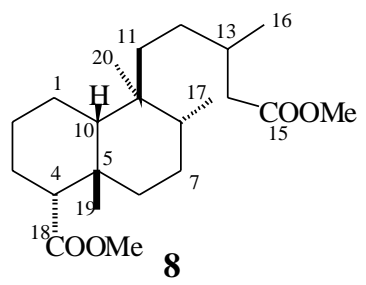<smiles>COC(=O)CC(C)C[C@]1(O)CCC2C(C)(C)CCC[C@]2(C)[C@@H]1C</smiles>

Scheme 2.

In order to investigate the two additional constituents of LC-4, this fraction was submited to further fractionation by HPLC (300 mm, $4.6 \mathrm{~mm}$ ID, $5 \mathrm{~mm}$, $\mu$-bondapak C-18) by using $90 \% \mathrm{CH}_{3} \mathrm{CN} / \mathrm{H}_{2} \mathrm{O}$ at $1.0 \mathrm{~mL} \mathrm{~min}^{-1}$. Fraction LC-4a, after methylation, upon GC-MS analysis, contained hardwickiic acid (methyl ester 6) and crolechinic acid (methyl ester 5), and LC-4b, after methylation, upon GC-MS analysis, contained patagonic acid (methyl ester 11) and its $\Delta^{3}$ saturated form, clerod-13-en-15,16-olide18-oic acid (methyl ester 12) (Scheme 3).

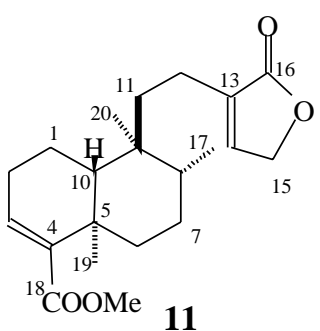

Scheme 3.

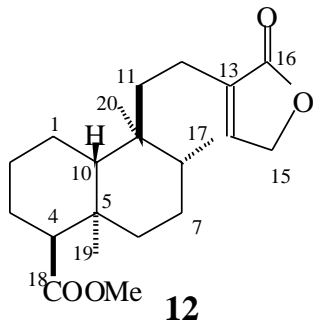

12
Fractionation by semipreparative HPLC opened the possibility of obtaining GC-IR data for fractions LC-2, LC-3 and LC-4b and provided amounts of fractions LC-1, LC-2, LC-3, LC-4a and LC-4b large enough to be analyzed by NMR $\left({ }^{1} \mathrm{H},{ }^{13} \mathrm{C}, \mathrm{COSY}\right.$, and HETCOR) which confirmed the above findings.

\section{Conclusions}

A fraction containing acid terpenes was conveniently isolated from the crude extract of Copaifera cearensis by silica gel/potassium hydroxide flash chromatography. The main components of this fraction were identified by 
GC-MS. Further fractionation of this extract by reversed phase semipreparative HPLC made it possible, not only to identify some minor constituents, but also to provide additional analytical data on the components of this acidic fraction. The stereochemistry of the compounds showed in the present paper are in agreement with those published in the literature and therefore, must be regarded as relative. The procedure described in the present paper was reproducible qualitatively and quantitatively. The use of this methodology will make possible the necessary quality control of copaiba oils which are commercially available at several drugstores. Based on IR analyses it was shown that the overall effect of washing silica with $\mathrm{KOH}$ was to decrease surface area, with deposition of $\mathrm{KOH}$ on the silica surface, in addition to formation of Si-OK due to a cation exchange process. In addition, as far as we know, this is the first time that the $\mathrm{KOH}$-modified silica gel, commonly used in chromatography $12,33,34$, is characterized by IR spectroscopy.

\section{Acknowledgements}

Financial support from CNPq, FNDCT/FINEP, CAPES, FUJB, FAPERJ and PRONEX (4002-96) is acknowledged. The authors are also grateful to Prof. NunoAlvares Pereira (Dept. of Pharmacology, Universidade Federal do Rio de Janeiro) for the provision of Copaifera cearensis Huber ex Ducke oil used in the present work and to Dr. Simon Garden, for useful suggestions and discussions.

\section{References}

1. Veiga Jr., V. F.; Patitucci, M. L.; Pinto, A. C. Quim. Nova 1997, 20, 612.

2. Lewis, W. H.; Elvin-Lewis, P. F. Medical Botany Plants Affecting Man's Health; John Wiley \& Sons: New York, 1977.

3. Dwyer, J. Brittonia 1951, 7, 143.

4. Mors, W. B.; Rizzini, C. T. Botânica Econômica Brasileira; Ed. Universidade de São Paulo: São Paulo, 1976.

5. Corrêa, M.P. Dicionário das Plantas Úteis do Brasil; Ministério da Agricultura: Rio de Janeiro, 1931; Vol. 2.

6. Carrara Jr., E.; Meirelles, H. A Indústria Química e o Desenvolvimento do Brasil - 1500-1889; Metalivros: São Paulo, 1996.

7. Osol, A.; Farrar, G. E. The Dispensatory of the USA, $25^{\text {th }}$ ed., 1955, p 1646.

8. Gilbert, B.; Mors, W. B.; Baker, P. M.; Tomassini, T. C.; Pellegrino, J. An. Acad. Bras. Cienc. 1972, 44, 423.

9. Basile, A. C.; Sertié, J. A. A.; Freitas, P. C. D.; Zanini, A. C. J. Ethnopharmacol. 1988, 22, 101.

10. Fernandes, R. M.; Pereira, N. A.; Paulo, L. G. Rev.
Bras. Farm. 1992, 73, 53.

11. McCarthy, R. D. G.; Duthie, A. H. I. J. Lipid Res. 1962, 3, 117.

12. Ramijak, Z.; Solc, A.; Arpino, P.; Schmitter, J. M.; Guiochon, G. Anal. Chem. 1977, 49, 1222.

13. Still, W. C.; Khan, M.; Mitra, A. J. Org. Chem. 1978, 43, 2923.

14. Sandermann, W.; Bruns, I. S.; Reichhelm, W. Tetrahedron Lett. 1982, 28, 2685.

15. Zeiss, H. H.; Grant Jr., F. W. J. Am. Chem. Soc. 1957, 79, 1201.

16. Mahajan, J. R.; Ferreira, G. A. L. An. Acad. Bras. Cienc. 1971, 43, 611.

17. Misra, R.; Pandey, R. C.; Dev, S. Tetrahedron 1979, 35, 979.

18. Cai, Y.; Chen, Z. P.; Phillipson, J. D. Phytochemistry 1993, 32, 755.

19. Costa, M.; Fujiwara, F. Y.; Imamura, P. M. Magn. Reson. Chem. 1998, 36, 542.

20. Braga, W. F.; Rezende, C. M.;Antunes, O. A. C.; Pinto, A. C. Phytochemistry 1998, 49, 263.

21. Tori, M.; Masaya, T.; Asakawa, Y. Phytochemistry 1993, 32, 1229.

22. Imamura, P. M.; Marsaioli, A. J.; Barata, L. E. S.; Rúveda, E. A. Phytochemistry, 1977, 16, 1842.

23. Ferrari, M.; Pellizzoni, F.; Ferrari, G. Phytochemistry 1971, 10, 3267.

24. Rivera, A. P.; Faini, F.; Castillo, M. J. Nat. Prod. 1988, $51,155$.

25. Bittner, M. L.; Zabel, V.; Smith, W. B.; Watson, W. H. Phytochemistry 1978, 17, 1797.

26. Wood, D. L.; Rabinovich, E. M.; Johnson Jr., D. W.; MacChesney, J. B.; Vogel, E. M. J. Am. Ceram. Soc. 1983, 66, 693.

27. Wood, D. L.; Rabinovich, E. M. Appl. Spectrosc.1989, 43, 263.

28. White, R. L.; Nair, A. Appl. Spectrosc.1990, 44, 69.

29. Kawano, Y.; Denofre, S.; Gushikem, Y. Vib. Spectrosc. 1994, 7, 293.

30. Nakamoto, K. Infrared and Raman Spectra of Inorganic and Coordination Compounds, Part A; Wiley-Interscience Publication: New York, $5^{\text {th }}$ ed., 1997, p 189-257.

31. Burneau, A.; Barrès, O.; Gallas, J. P.; Lavalley, J. C. Langmuir, 1990, 6, 1364.

32. Colthup, N. B.; Daly, L. H.; Wiberley, E. Introduction to Infrared and Raman Spectroscopy, Academic Press: New York, $3^{\text {rd }}$ Ed., 1990, p 210.

33. Khulbe, K. C.; Mann, R. S.; MacPhee, J. A. Fuel Process. Technol. 1996, 46, 63.

34. Lebo, J. A.; Zajicek, J. L.; May, T. W.; Smith, L. M. J. Assoc. Off. Anal. Chem. 1989, 72, 371. 